5. Руководство по гидробиологическому мониторингу пресноводных экосистем / под ред. В.А. Абакумова. СПб.: Гидрометеоиздат, 1992. С. 131-150.

6. Определитель пресноводных беспозвоночных Европейской части СССР. Планктон, бентос. Л.: Гидрометеоиздат, 1977. $513 \mathrm{c.}$

7. Определитель пресноводных беспозвоночных России и сопредельных территорий. Т. 3. Паукообразные. Низшие насекомые. СПб.: Наука, 1997. 225 с.

8. Степановских А.С. Экология: учебник для вузов. М.: ЮНИТИ-ДАНА, 2001. С. 288.

9. Государственный доклад «О состоянии природных ресурсов и окружающей среды республики Башкортостан в 2005 году». Уфа, 2006. 197 с.

10. Государственный доклад «О состоянии природных ресурсов и окружающей среды республики Башкортостан в 2006 году». Уфа, 2007. 200 с.
11. Государственный доклад «О состоянии природных ресурсов и окружающей среды республики Башкортостан в 2007 году». Уфа, 2008. 217 с.

12. Государственный доклад «О состоянии природных ресурсов и окружающей среды республики Башкортостан в 2008 году». Уфа, 2009. 200 с.

13. Государственный доклад «О состоянии природных ресурсов и окружающей среды республики Башкортостан в 2009 году». Уфа, 2010. 189 с.

14. Государственный доклад «О состоянии природных ресурсов и окружающей среды республики Башкортостан в 2010 году». Уфа, 2011. 343. 197 с.

15. Государственные доклады «О состоянии природных ресурсов и окружающей среды республики Башкортостан». Уфа, 2011-2016 [Электронный реcypc] // http:// ecology.bashkortostan.ru/presscenter/ lectures.

\title{
LARVAE OF EPHEMEROPTERA GROUP AS BIOINDICATORS OF WATER QUALITY OF THE SOUTH URAL RIVERS
}

(C) 2017

Chaus Boris Yuryevich, candidate of biological sciences, associate professor of Biology Department Sterlitamak branch of Bashkir State University (Sterlitamak, Republic of Bashkortostan, Russian Federation)

Abstract. The paper contains the analysis of a possibility to use green drakes larvae of Ephemeroptera group for bioindicator researches during environmental monitoring of the South Ural rivers. Collection and analysis of types constancy of green drakes larvae was carried out in 2005 to 2016 in 17 state water posts on the territory of the South Ural rivers. As chemical characteristics the author used the index of content of compounds of manganese, nickel and iron, oil products, phenols, nitrogen ammonium, coppers, zinc, chemical oxygen consumption (COC), biological oxygen consumption in 5 days $\left(\mathrm{BOC}_{5}\right)$, sulfates, chlorides, nitrite nitrogen in river waters. In total constancy dynamics of 13 species larvae of mayflies was analyzed. The author has made a list of constant, additive and casual types of representatives of Ephemeroptera group. Significant correlative dependences between constancy of larvae of species of mayflies with a number of hydrochemical indexes are revealed statistically. The paper contains regression models for the constancy forecast of larvae of green drakes depending on concentration of the pollutant.

Keywords: bioindication; green drakes; larvae of green drakes; Ephemeroptera group; South Ural; constancy of types; dynamics of constancy; hydrochemical indexes; pollutant; specific combinatorial index of impurity of water; correlative models; regression models.

УДК 57.044

Статья поступила в редакцию 14.10.2017

\section{БИОГЕОХИМИЧЕСКАЯ ХАРАКТЕРИСТИКА ПАРКОВ И СКВЕРОВ РОСТОВА-НА-ДОНУ} (C) 2017

\author{
Шишкина Диана Юрьевна, кандидат географических наук, \\ доцент кафедры геоэкологии и прикладной геохимии \\ Южный федеральный университет (2. Ростов-на-Дону, Российская Федераиия)
}

Аннотация. Изучено распределение тяжелых металлов и мышьяка в почвах и листьях робинии обыкновенной на территории парков и скверов Ростова-на-Дону. Отобраны 81 проба почвы и 30 проб листьев в 13 парках города. Для определения концентраций элементов использовался приближенно-количественный и атомно-абсорбционный анализы. По всем элементам рассчитывался коэффициент концентрации, а также коэффициент опасности, представляющий кратность превышения ПДК или ОДК. Суммарный показатель загрязнения $\left(\mathrm{Z}_{\mathrm{c}}\right)$, представляющий собой сумму превышений концентраций отдельных элементов над фоновым уровнем, применялся для характеристики комплексного загрязнения. При сопоставлении средних концентраций металлов и мышьяка с естественным педогеохимическим фоном выявляется геохимическая ассоциация: $\mathrm{Cu}_{2,5} \mathrm{Zn}_{2,3} \mathrm{~Pb}_{1,8} \mathrm{~V}_{1,3} \mathrm{Hg}_{1,3} \mathrm{Ni}_{1,2} \mathrm{Cd}_{1,2}$, типичная для почв Ростова-на-Дону. Выявлено слабо локальное загрязнение почв парков и скверов цинком, медью, ванадием и свинцом. Самым распространенным поллютантом является цинк, для него же характерно наибольшее превышение ОДК. Загрязнение почвенного покрова рекреационных зон оценивается как допустимое. С течением времени происходит снижение концентраций цинка и рост концентраций меди и ванадия в почвах парковых ландшафтов. Наблюдается усиление биологического поглощения листьями робинии меди и молибдена.

Ключевые слова: Ростов-на-Дону; тяжелые металлы; парки и скверы; коэффициент опасности; коэффициент концентрации; суммарный показатель загрязнения; коэффициент биологического поглощения; геохимический фон; чернозем; робиния обыкновенная; геохимические ассоциации; цинк; ванадий; медь; свинец; молибден; допустимое загрязнение почв. 
Изучение распределения тяжелых металлов и мышьяка в почвах и растениях городских рекреационных зон (парков, скверов, лесопарков и др.) является неотъемлемой частью комплексных экологогеохимических исследований урболандшафтов $[1 ; 2]$. Оценка эколого-геохимической ситуации в зелёных зонах важна также с позиции обеспечения оптимальных условий произрастания растений, сохранения рекреационного потенциала городских фитоценозов, поэтому эта тема привлекает внимание многих ученых и как отдельная научная проблема [3-7].

Подобного рода работы выполнялись и в Ростовена-Дону [8-10]. Как правило, они охватывали территории не более чем трех парков, изучался узкий спектр элементов в небольшом количестве почвенных проб. Некоторые аспекты распределения и миграции тяжелых металлов в почвах парковых ландшафтов на представительном фактическом материале рассматривались нами ранее [11]. В настоящей работе наряду с изложением выявленных особенностей пространственного распределения тяжелых металлов (ТМ) и мышьяка в почвах парков рассматриваются еще и закономерности биогенной миграции и накопления металлов в листьях деревьев, а также временная динамика концентраций ТМ в почвах рекреационных ландшафтов.

\section{Объекты и методы исследований}

Зональным типом почв, развитых на территории Ростова-на-Дону, являются черноземы обыкновенные среднемощные малогумусные суглинистые карбонатные. Эти почвы относятся к ПриазовскоПредкавказской почвенной провинции $\left(Ж 2_{3}\right)$ черноземов обыкновенных теплых кратковременно промерзающих южно-европейской фации. В настоящее время почвенный покров в пределах города полностью и глубоко преобразован, естественные почвы практически не сохранились.
На территории Ростова-на-Дону расположены 14 парков, 31 сквер, сады отсутствуют. Общая площадь объектов по состоянию на 2011 г. составляет 184,7 га, озелененная - 146, 24 га [12]. Городские парки, сады и скверы по структуре и видовому составу можно разделить на три группы. К первой относятся старые парки, сады и скверы, заложенные ещё в конце XIX - начале XX веков и подвергшиеся капитальной реконструкции в 1950-х гг.: МУ «Детский парк им. В. Черевичкина», сквер Строителей, парк ДГТУ им. Л.В. Красниченко, МУП ГКДЦ им. М. Горького, парк Островского, МУ Парк культуры и отдыха «1 Мая». Объекты второй группы заложены или реконструированы в 1960-1970-х гг. (ПКиО им. г. Плевен). Третья группа - новые парки - основанные в конце XX - начале XXI вв. (ПКиО «Дружба») [13]. Некоторые характеристики парков и скверов Ростова-на-Дону приведены в табл. 1.

В основу работы положены материалы экологогеохимических исследований, проведенных в 2013 г. на территории девяти парков и включавших опробование верхнего почвенного горизонта и листьев робинии обыкновенной (Robinia pseudoakacia) - одного из наиболее распространенных деревьев Ростова-наДону, часто ошибочно называемого «белой акацией». Было отобрано 77 почвенных проб (в каждом парке - от 6 до 10) и 30 проб листьев робинии (по 3 пробы из каждого парка). Следует отметить, что парк им. г. Плевен разделен площадью и улицей с интенсивным транспортным потоком на два участка, Верхний и Нижний (Аллея роз), которые в дальнейшем рассматривались обособленно. В ходе проведенной в 2015 г. эколого-геохимической съемки Октябрьского района Ростова-на-Дону были изучены территории четырех парков. Таким образом, общее количество педогеохимических проб - 81 .

Таблица 1 - Общая характеристика парков и скверов Ростова-на-Дону [по 12; 14]

\begin{tabular}{|l|c|c|c|c|}
\hline \multicolumn{1}{|c|}{ Наименование } & $\begin{array}{c}\text { Классифи- } \\
\text { кация }\end{array}$ & $\begin{array}{c}\text { Год } \\
\text { основания }\end{array}$ & $\begin{array}{c}\text { Площадь общая / } \\
\text { озелененная, га }\end{array}$ & $\begin{array}{c}\text { Густота посадки } \\
\text { деревьв, шт./га }\end{array}$ \\
\hline МУП ГКДЦ им. М. Горького & парк & 1813 & $9,1 / 5,34$ & 450 \\
\hline МУ ПКиО «1 Мая» & парк & 1855 & $4,3 / 3,35$ & 400 \\
\hline МУ «Детский парк им. В. Черевичкина» & парк & 1880 & $2,8 / 1,65$ & 489 \\
\hline ПКиО им. Н. Островского & парк & 1884 & $24,4 / 17$ & 550 \\
\hline Парк ДГТУ им. Л.В. Красниченко & парк & 1900 & $13 / 10,2$ & 461 \\
\hline Строителей & сквер & 1903 & $1,36 / 0,84$ & 430 \\
\hline Пионерский & сквер & $1910-1915$ & $2,14 / 2,1$ & 231 \\
\hline Им. К. Чуковского & сквер & 1937 & $9,83 / 8,97$ & 339 \\
\hline МУ им. Октября & парк & 1971 & $7,2 / 6,4$ & 465 \\
\hline ПКиО им. г. Плевен & парк & 1975 & $17,1 / 12,6$ & 385 \\
\hline «Дружба» на бул. Комарова & парк & 2003 & $4,0 / 3,3$ & 150 \\
\hline Комсомольский & сквер & не известен & $3,67 / 2,85$ & 440 \\
\hline
\end{tabular}

В региональном лабораторном центре ОАО «Южгеология» в почве и золе листьев приближенно-количественным спектральным анализом определены концентрации 35 элементов, из которых для дальнейшего изучения распределения в почве выбраны $\mathrm{Mn}, \mathrm{Ni}, \mathrm{V}, \mathrm{Cu}, \mathrm{Pb}, \mathrm{Zn}$; в растениях - Mo, Mn, $\mathrm{Ni}, \mathrm{Cu}$, $\mathrm{Pb}, \mathrm{Zn}$. В испытательном лабораторном центре ФБУЗ «Центр гигиены и эпидемиологии в Ростовской области» почвенные пробы методом атомно-эмиссионной спектрометрии анализировались на содержание $\mathrm{Cd}, \mathrm{Hg}$, As.
Эколого-геохимическая оценка выполнялась на основе анализа коэффициента концентрации $\left(\mathrm{K}_{\mathrm{c}}\right)$ отдельных элементов относительно их фоновых значений и коэффициента опасности $\left(K_{\mathrm{o}}\right)$ - кратности превышения ПДК (ОДК) отдельных элементов [15, с. 83; 16]. Для характеристики комплексного загрязнения применялся суммарный показатель загрязнения $\left(\mathrm{C} \Pi 3, \mathrm{Z}_{\mathrm{c}}\right)$, представляющий собой аддитивную сумму превышений концентраций отдельных элементов над единичным (фоновым) уровнем: 


$$
\mathrm{Z}_{\mathrm{c}}=\Sigma \mathrm{K}_{\mathrm{c}}-(\mathrm{n}-1),
$$

где $K_{c}-$ коэффициент концентрации, $n-$ число химических элементов, входящих в изучаемую ассоциацию [15, с. 38].

При $Z_{c}$, меньшем 16, категория загрязнения оце-

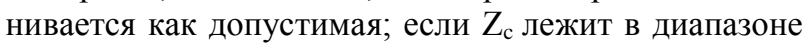
16-32 - умеренно опасная; в диапазоне 32-128 опасная; при $Z_{c}$, большем 128 , категория загрязнения - чрезвычайно опасная [17].

Оценка степени загрязнения почв проводилась на основе санитарно-гигиенических нормативов - ПДК и ОДК химических элементов [18; 19]. В качестве геохимического фона приняты средние концентрации химических элементов в черноземах в пределах природных ландшафтов Ростовской области [20].

Для оценки интенсивности поглощения растениями химических элементов из почвы использовался коэффициент биологического поглощения $\mathrm{A}_{\mathrm{x}}$ (КБП):

$$
\mathrm{A}_{\mathrm{x}}=1 / \mathrm{n},
$$

где $l$ - содержание элемента в золе растения, $n$ - его концентрация в почве, на которой оно растет [21].
Способность растения к концентрации микроэлементов может быть выражена через показатель биогеохимической активности вида (БХА) [22], представляющий собой величину, образующуюся от сложения коэффициентов поглощения отдельных микроэлементов:

$$
\mathrm{БXA}=\Sigma \mathrm{A}_{\mathrm{x}} .
$$

\section{Результаты исследований}

Распределение цинка отличается высокой контрастностью: в почвах различных рекреационных зон его содержание варьирует от 60 до 800 мг/кг (табл. 2). Наиболее высокие средние концентрации отмечены в почвах старых парков, находящихся в центре города: им. В. Черевичкина, 1 Мая, им. Н. Островского (табл. 3). Превышение содержаний $\mathrm{Zn}$ по отношению к ОДК зафиксировано в почвах восьми парков. Самый высокий $\mathrm{K}_{\text {o, }}$ равный 3,6, характерен для парка им. В. Черевичкина; наиболее обширной площадью загрязнения (шесть проб из восьми) отличается парк «1 Мая». Цинк - наиболее распространенный элемент-загрязнитель почв в парках, как, впрочем, и в других функциональных зонах и районах Ростова-на Дону [23-25].

таблица 2 - Пределы колебаний концентраций химических элементов в почвах парков Ростова-на-Дону, Мг/Кг

\begin{tabular}{|l|c|c|c|c|c|c|}
\hline \multicolumn{1}{|c|}{ Парки } & \multicolumn{5}{c|}{ Химические элементы } \\
\cline { 2 - 7 } & $\mathrm{Pb}$ & $\mathrm{Zn}$ & $\mathrm{Ni}$ & $\mathrm{Cu}$ & $\mathrm{Mn}$ & $\mathrm{V}$ \\
\hline им. М. Горького & $15-60$ & $60-300$ & $40-60$ & $50-80$ & $700-1000$ & $100-200$ \\
\hline «1 Мая» & $20-80$ & $150-500$ & $40-60$ & $80-100$ & $700-800$ & $80-150$ \\
\hline им. В. Черевичкина & $20-200$ & $100-800$ & $40-50$ & $50-200$ & $500-800$ & $60-200$ \\
\hline им. Н. Островского & $20-150$ & $100-600$ & $30-50$ & $60-150$ & $600-1000$ & $80-150$ \\
\hline Строителей & $20-60$ & $100-300$ & $40-50$ & $50-100$ & $700-1000$ & $100-150$ \\
\hline Пионерский & $20-60$ & $80-200$ & $50-80$ & $60-100$ & $700-1000$ & $100-150$ \\
\hline им. Г. Плевен (Верхний) & $15-40$ & $80-150$ & $50-100$ & $50-100$ & $700-800$ & $100-150$ \\
\hline им. Г. Плевен (Нижний, Аллея роз) & $15-60$ & $80-500$ & $40-50$ & $50-100$ & $600-800$ & $60-150$ \\
\hline «Дружба» & $10-40$ & $80-150$ & $30-60$ & $50-150$ & $600-1000$ & $60-150$ \\
\hline им. 8 Марта & $20-100$ & $80-300$ & $40-50$ & $60-300$ & $600-800$ & $100-200$ \\
\hline
\end{tabular}

таблица 3 - Среднее содержание химических элементов в почвах парков Ростова-на-Дону, мг/кг

\begin{tabular}{|l|c|c|c|c|c|c|c|c|c|}
\hline \multirow{2}{*}{\multicolumn{1}{|c|}{ Парки }} & \multicolumn{9}{c|}{ Химические элементы } \\
\cline { 2 - 10 } & $\mathrm{Pb}$ & $\mathrm{Zn}$ & $\mathrm{Cd}$ & $\mathrm{Hg}$ & $\mathrm{As}$ & $\mathrm{Ni}$ & $\mathrm{Cu}$ & $\mathrm{Mn}$ & $\mathrm{V}$ \\
\hline им. М. Горького & 39,3 & 180,0 & 0,5 & 0,045 & 2,4 & 47,1 & 67,1 & 785,7 & 142,9 \\
\hline Пионерский & 41,4 & 154,3 & 0,3 & 0,033 & 2,1 & 57,1 & 71,4 & 814,3 & 128,6 \\
\hline им. 8 Марта & 40,0 & 143,0 & 0,3 & 0,026 & 3,0 & 45,0 & 102,0 & 750,0 & 150,0 \\
\hline им. Н. Островского & 48,8 & 250,0 & 0,5 & 0,033 & 1,5 & 37,5 & 91,3 & 787,5 & 122,5 \\
\hline «Дружба» & 21,7 & 106,7 & 0,5 & 0,014 & 1,2 & 47,8 & 81,1 & 788,9 & 110,0 \\
\hline Строителей & 36,7 & 191,7 & 0,18 & 0,02 & 2,0 & 46,7 & 85,0 & 816,7 & 133,3 \\
\hline им. В. Черевичкина & 77,5 & 300,0 & 0,4 & 0,041 & 2,0 & 45,0 & 138,8 & 687,5 & 117,5 \\
\hline им. Г. Плевен (Верхний) & 30,0 & 122,5 & 0,2 & 0,021 & 1,3 & 62,5 & 73,8 & 750,0 & 112,5 \\
\hline «1 Мая» & 43,8 & 312,5 & 0,4 & 0,043 & 1,6 & 42,5 & 92,5 & 750,0 & 116,3 \\
\hline им. г. Плевен (Нижний, Аллея роз) & 39,2 & 188,3 & 0,3 & 0,021 & 1,0 & 45,0 & 75,0 & 666,7 & 106,7 \\
\hline им. Октября & 60,0 & 200,0 & 0,06 & 0,01 & 3,7 & 60,0 & 80,0 & 800,0 & 150,0 \\
\hline им. К. Чуковского & 20,0 & 150,0 & 0,13 & 0,007 & 5,6 & 50,0 & 60,0 & 600,0 & 150,0 \\
\hline Комсомольский сквер & 80,0 & 400,0 & 0,07 & 0,007 & 6,5 & 40,0 & 60,0 & 600,0 & 200,0 \\
\hline Парк ДГТУ им. Л.В. Красниченко & 20,0 & 80,0 & 0,07 & 0,007 & 2,3 & 60,0 & 50,0 & 700,0 & 150,0 \\
\hline Среднее по паркам & 42,2 & 192,5 & 0,27 & 0,024 & 2,7 & 48,6 & 87,0 & 764,5 & 126,2 \\
\hline Региональный фон & 24,0 & 84,3 & 0,22 & 0,018 & 4,76 & 41,0 & 34,8 & 725,0 & 96,0 \\
\hline ПДК (ОДК) & 130 & 220 & 2,0 & 2,1 & 10 & 80 & 132 & 1500 & 150 \\
\hline
\end{tabular}

На высокие концентрации металла обращают внимание и другие ученые. Так, по данным О.А. Капраловой и С.И. Колесникова концентрации Zn выше регионального фона обнаружены во всех образцах парковых почв: парк им. г. Плевен - 92 мг/кг, «Дружба» - 100, им. Н. Островского - 434, парк ДГТУ им. Л.В. Красниченко - 437 мг/кг. Среднее содержание 212,9 мг/кг [8]. В работе Е.В. Налета с соавторами 
приводятся следующие содержания металла: парк им. В. Черевичкина - 200, им. М. Горького 219 мг/кг [9]. Е.О. Гудзенко, изучая состояние зеленых насаждений Ростова-на-Дону, установила, что концентрация $\mathrm{Zn}$ в почве скверов Дортмундский, Осенний и им. Первого пионерского слета составляет, соответственно, 145,5, 162,3 и 112,9 мг/кг [10]. При общей схожести концентраций обращает на себя внимание расхождение между данными по парку ДГТУ им. Л.В. Красниченко, что можно объяснить различиями во времени пробоотбора. Исследования О.А. Капраловой и С.И. Колесникова проводились до начавшейся в 2013 г. реконструкции парка [26], в ходе которой почвенный покров на многих участках был обновлен.

На территории пяти парков выявлено слабое $\left(K_{o}=1,3\right)$ загрязнение почв ванадием, концентрации которого достигают 200 мг/кг. В почвах вышеперечисленных скверов содержание элемента изменяется от 103,1 до 122,3 мг/кг [10]. Концентрации свинца изменяются от 10 до 200 мг/кг, причем тенденции пространственного распределения, выявленные для цинка, распространяются и на поведение свинца. Отличается лишь уровень и площадь загрязнения: максимальные концентрации превосходят санитарногигиенический норматив в 1,5 раза, загрязнение выявлено лишь в двух пробах.

Парковые почвы отличаются от почв прочих функциональных зон города высокими содержаниями меди. Максимальные ее концентрации на территории парка им. 8 Марта достигают 300 мг/кг, что в 2,6 раза выше ОДК. Медное загрязнение выявлено в восьми почвенных пробах на территории четырех парков. Возможно, высокие концентрации меди обусловлены применением медьсодержащих пестицидов (бордосской жидкости) при выращивании парковых культур.

Концентрации остальных элементов - кадмия, ртути, никеля, марганца - незначительно превышают региональный фон, но не достигают санитарногигиенических нормативов. Таким образом, почвы городских парков и скверов слабо загрязнены тяжелыми металлами. Наиболее широко распространено цинковое загрязнение (присутствует в $22 \%$ отобранных проб), далее медное (10\%), затем ванадиевое $(6 \%)$ и свинцовое $(3 \%)$.

Полученные данные позволяют ранжировать парки по средней величине $Z_{c}$ и выявить уровень комплексного загрязнения: парк ДГТУ им. Л.В. Красниченко $(2,46)$ - «Дружба» $(3,27)-$ им. К. Чуковского $(3,47)$ - им. г. Плевен (Верхний) $(3,71)$ - им. г. Плевен (Нижний) $(4,51)$ - Пионерский $(4,71)$ - им. 8 Марта $(4,81)$ - им. М. Горького $(4,97)$ - Строителей $(5,21)-$ им. Октября $(6,3)$ - им. Н. Островского $(6,38)$ - «1 Мая» $(6,83)$ - Комсомольский $(9,25)$ - им. В. Черевичкина $(9,47)$.

Выявляется четкая тенденция роста концентраций химических элементов в почвах старых парков. Низкие значения СПЗ характерны для парков, основанных в конце XX - начале XXI в. на окраинах города - им. г. Плевен и «Дружба». Следует отметить, что последний разбит на месте бывшего глиняного карьера и рассматривается как пример удачной рекультивации [27]. Для всех парков категория загрязнения почв оценена как допустимая, и лишь в одной пробе в пределах парка им. В. Черевичкина величина $\mathrm{Z}_{\mathrm{c}}(17,66)$ соответствует умеренно-опасной категории.

В ходе ретроспективного анализа эколого-геохимической ситуации, основанного на сравнении с результатами эколого-геохимической съемки северозападной части Ростова-на-Дону, проведенной в 1994 г. [28], выявлено снижение концентрации цинка. В 1994 г. его среднее содержание в почвах рекреационных ландшафтов составляло 284,1 мг/кг, при этом максимальная концентрация достигала 2000 мг/кг. Среднее содержание меди в парковых почвах за 20 лет выросло в 1,5 раза, ванадия - в 1,3 раза; концентрации остальных элементов практически не изменились.

Содержание цинка с течением времени резко снизилось и в листьях деревьев, хотя здесь необходимо учитывать возможные различия в способности тополя черного (Populus nigra) и робинии к биоаккумуляции. При вполне сопоставимых содержаниях никеля, молибдена, меди и свинца зола листьев тополя отличается высокими средними концентрациями цинка и марганца, превосходящими таковые в золе листьев робинии в 4,6 и 4,5 раза (табл. 4).

таблица 4 - Содержание химических элементов в золе листьев деревьев, мг/кг

\begin{tabular}{|l|c|c|c|c|c|}
\hline \multirow{2}{*}{$\begin{array}{c}\text { Химиче- } \\
\text { ские } \\
\text { элементы }\end{array}$} & \multicolumn{2}{|c|}{ Тополь, 1994 г. } & \multicolumn{3}{|c|}{ Робиния, 2013 г. } \\
\cline { 2 - 6 } Мределы & $\begin{array}{c}\text { сред- } \\
\text { нее }\end{array}$ & пределы & $\begin{array}{c}\text { сред- } \\
\text { нее }\end{array}$ & КБП \\
\hline Марганец & $\begin{array}{c}100- \\
3000\end{array}$ & 856,6 & $40-600$ & 186,7 & 0,26 \\
\hline Микель & $10-200$ & 35,2 & $1-80$ & 37,8 & 0,95 \\
\hline Молибден & $1,5-15$ & 3,9 & $1-15$ & 5,5 & 1,78 \\
\hline Свинец & $30-100$ & 51,5 & $20-100$ & 50,3 & 1,44 \\
\hline Цинк & $8-60$ & 17,1 & $4-20$ & 8,1 & 0,34 \\
\hline
\end{tabular}

Определение коэффициентов биологического поглощения элемента и сопоставление их с градацией А.И. Перельмана показывает, что робиния в ростовских парках и скверах более интенсивно накапливает медь и молибден. А.И. Перельман относил эти элементы к группе среднего биологического захвата с $\mathrm{A}_{\mathrm{x}}$ в диапазоне $0,1-1$. В нашем случае происходит усиление биологического поглощения меди и молибдена, численно выражаемое КБП 1,44 и 1,78, и переход их в группу сильного биологического накопления. Подобная тенденция выявлена ранее для основных сельскохозяйственных культур Ростовской области [29].

\section{Выводы}

1. При сопоставлении средних концентраций металлов и мышьяка с естественным педогеохимическим фоном выявляется геохимическая ассоциация: $\mathrm{Cu}_{2,5} \mathrm{Zn}_{2,3} \mathrm{~Pb}_{1,8} \mathrm{~V}_{1,3} \mathrm{Hg}_{1,3} \mathrm{Ni}_{1,2} \mathrm{Cd}_{1,2}$. В целом такой ряд характерен для почв всех урболандшафтов Ростована-Дону, но обычно первую позицию занимает цинк.

2. Выявлено слабо локальное загрязнение почв парков и скверов цинком, медью, ванадием и свинцом. Самым распространенным поллютантом является цинк, для него же характерно наибольшее превышение ОДК.

3. Загрязнение почвенного покрова рекреационных зон оценивается как допустимое; лишь в одной точке пробоотбора - умеренно опасное.

4. Временная динамика эколого-геохимической ситуации проявляется в снижении концентраций 
цинка при одновременном росте содержания меди и ванадия в почвах парковых ландшафтов.

5. Наблюдается усиление биологического поглощения листьями робинии меди и молибдена и переход их из группы среднего биологического захвата в группу сильного биологического накопления.

\section{СПИСОК ЛИТЕРАТУРЫ:}

1. Ачкасов А.И., Варава К.В., Самаев С.Б., Башкаревич И.Л., Трефилова Н.Я. Интенсивность и тенденции изменения химического загрязнения почв Москвы // Геоэкологические проблемы Новой Москвы. М., 2013. С. 65-69.

2. Старцев А.И., Прохорова Н.В. Эколого-геохимические особенности почв разных функциональных зон города Новокуйбышевска // Самарский научный вестник. 2017. Т. 6, № 1. С. 83-88.

3. Аткина Л.И., Жукова М.В., Морозов А.М., Данилов Д.А. Загрязнение почв парка им. 50-летия ВЛКСМ г. Екатеринбурга тяжелыми металлами // Современные проблемы науки и образования. 2014. № 5. С. 756 .

4. Дабахов М.В., Чеснокова Е.В. Тяжелые металлы в почвах парков заречной части Нижнего Новгорода // Вестник Нижегородского университета им. Н.И. Лобачевского. 2010. № 2-1. С. 109-116.

5. Хачоян А.Г., Оганесян А.А., Нерсисян Г.С., Бужделев В.В. Биогеохимическое исследование Кольцевого парка города Еревана // Антропогенная трансформация природной среды. 2012. № 1. С. 198-202.

6. Казанцев И.В., Матвеева Т.Б., Молчатский С.Л. Содержание тяжелых металлов в почвенном покрове пригородных лесов города Самары // Карельский научный журнал. 2015. № 4. С. 83-86.

7. Прокофьева Е.В., Еремин В.Н., Решетников М.В., Шешнев А.С. Тяжелые металлы в почвах на территории памятника природы «Городской парк культуры и отдыха города Саратова» // Известия Самарского научного центра РАН. 2016. Т. 18, № 1-1. С. 34-38.

8. Капралова О.А., Колесников С.И. Влияние загрязнения тяжелыми металлами на эколого-биологические свойства почв г. Ростова-на-Дону // Научная мысль Кавказа. 2012. № 1. С. 69-72.

9. Налета Е.В., Капралова О.А., Казеев К.Ш., Колесников С.И. Изменение биологических свойств почв крупных городов Ростовской области под влиянием загрязнения тяжелыми металлами // Современные проблемы науки и образования. 2013. № 6. С. 716.

10. Гудзенко Е.О. Оценка экологического состояния зеленых насаждений города Ростова-на-Дону: автореф. дис. ... канд. биол. наук. Ростов-н/Д., 2016. $23 \mathrm{c.}$

11. Шишкина Д.Ю. Тяжелые металлы в почвах парков Ростова-на-Дону // Экология родного края: проблемы и пути решения: сб. материалов всерос. науч.-практ. конф. Книга 2. Киров: Изд-во ООО «Радуга-ПРЕСС», 2016. С. 67-70.

12. Жукова Е.О., Козловский Б.Л., Паршин В.Г. Оценка состояния зеленых насаждений парков, садов и скверов города Ростов-на-Дону // Вестник ИрГCXA. 2011. Т. 5, № 44. С. 34-40.

13. Похилько Л.О. Экологические принципы формирования ассортимента древесных растений в озеленении г. Ростова-на-Дону: автореф. дис. ... канд. биол. наук. Ростов-н/Д., 2009. 25 с.
14. Вдовин М.А. Сад нашего предвоенного детства // Донской временник. Год 1999. Ростов-н/Д., 1998. С. 106-107.

15. Сает Ю.Е., Ревич Б.А., Янин Е.П. Геохимия окружающей среды. М.: Недра, 1990. 335 с.

16. МУ 2.1.7.730-99. Гигиеническая оценка качества почвы населенных мест. Методические указания. М.: Федеральный центр госсанэпиднадзора Минздрава России, 1999. 38 с.

17. СанПиН 2.1.7.1287-03. Санитарно-эпидемиологические требования к качеству почвы. Изд. 2-е, стереотип. М.: Федеральный центр гигиены и эпидемиологии Роспотребнадзора, 2005. 19 с.

18. ГН 2.1.7.2041-06. Предельно-допустимые концентрации (ПДК) химических веществ в почве: Гигиенические нормативы. М.: Федеральный центр гигиены и эпидемиологии Роспотребнадзора, 2006. 15 с.

19. ГН 2.1.7.2511-09. Ориентировочно-допустимые концентрации (ОДК) химических веществ в почве: Гигиенические нормативы. М.: Федерал. центр гигиены и эпидемиологии Роспотребнадзора, 2009. 11 с.

20. Коханистая Н.В., Шишкина Д.Ю. Определение регионального педогеохимического фона (на примере Ростовской области) // Сотрудничество стран БРИКС для устойчивого развития: матер. междунар. конф. Ростов н/Д., 2015. Т. 2. С. 295-298.

21. Перельман А.И. Геохимия ландшафта. М.: Географгиз, 1961. $391 \mathrm{c.}$

22. Айвазян А.Д. Геохимические особенности флоры ландшафтов юго-западного Алтая: автореф. дис. ... канд. геогр. наук. М., 1974. 24 с.

23. Шишкина Д.Ю. Тяжелые металлы в почвах урболандшафтов г. Ростова-на-Дону // Известия высших учебных заведений. Северо-Кавказский регион. Естественные науки. 2015. № 2. С. 101-105.

24. Шишкина Д.Ю., Белая Т.Г. Эколого-геохимическая оценка почвенного покрова Октябрьского района Ростова-на-Дону // Известия высших учебных заведений. Северо-Кавказский регион. Естественные науки. 2016. № 3. С. 110-115.

25. Shishkina D. Chemical contaminations of soils of industrial urban landscapes South of Russia // 17th International Multidisciplinary Scientific Geoconferernce SGEM 2017: Conference Proceedings. Vol. 17. Ecology, Economics, Education and Legislation. Iss. 5. 29 June 5 July, 2017. Albena, Bulgaria, 169-174 p.

26. Ермолаева О.Ю., Шарапов Д.Ю., Хворост Е.И. Парк ДГТУ им. Л.В. Красниченко (г. Ростов-на-Дону): история создания и ландшафтная структура // APRIORI. Серия: естественные и технические науки. 2015. № 5. C. 12.

27. Гарнизоненко Т.С., Паршин В.Г., Рязанова О.Н. Ассортимент и ландшафтная структура некоторых парков г. Ростова-на-Дону // Интродукция, сохранение и использование биологического разнообразия мировой флоры: мат-лы междунар. конф., посв. 80летию Центрального ботанического сада Национальной академии наук Беларуси. 19-22 июня 2012 г. Мн., 2012. С. 395-399.

28. Закруткин В.Е., Скрипка Г.И., Шишкина Д.Ю. Эколого-геохимическая оценка ландшафтов Ростована-Дону в зоне влияния РТЭЦ-3 // Известия высших учебных заведений. Северо-Кавказский регион. Естественные науки. 1996. № 3. С. 55-63.

29. Шишкина Д.Ю. Геохимия меди и цинка в агроландшафтах Ростовской области: автореф. дис. ... канд. геогр. наук. Ростов н/Д., 2000. 26 с. 


\title{
BIOGEOCHEMICAL CHARACTERISTICS OF PARKS AND PUBLIC GARDENS IN ROSTOV-ON-DON
}

(C) 2017

\author{
Shishkina Diana Yurievna, candidate of geographical sciences, \\ associate professor of Geoecology and Applied Geochemistry Department \\ Southern Federal University (Rostov-on-Don, Russian Federation)
}

\begin{abstract}
The distribution of heavy metals and arsenic in the soils and leaves of the locust in the parks and squares of Rostov-on-Don was studied. 81 samples of soil and 30 samples of leaves were selected in 13 parks of the city. To determine the concentrations of elements, we used the approximate-quantitative and atomic-absorption analyses. For all elements, the concentration coefficient was calculated, as well as the hazard factor representing the multiplicity of exceeding the MAC or AAC. The total pollution index $\left(\mathrm{Z}_{\mathrm{c}}\right)$, which is the sum of the excess concentrations of individual elements above the background level, was used to characterize complex pollution. When comparing the average concentrations of metals and arsenic with the natural pedogeochemical background, a geochemical association is revealed: $\mathrm{Cu}_{2,5} \mathrm{Zn}_{2,3} \mathrm{~Pb}_{1,8} \mathrm{~V}_{1,3} \mathrm{Hg}_{1,3} \mathrm{Ni}_{1,2} \mathrm{Cd}_{1,2}$, typical of Rostov-on-Don soils. Weakly local pollution of soils of parks and squares with zinc, copper, vanadium and lead was revealed. The most common pollutant is zinc, for which the highest excess of AAC is characteristic. Pollution of the soil cover of recreational areas is assessed as permissible. With the passage of time, the concentration of zinc decreases and the concentrations of copper and vanadium increase in the soils of park landscapes. There has been increasing biological absorption by the leaves of the locust copper and molybdenum.

Keywords: Rostov-on-Don; heavy metals; parks and public gardens; danger coefficient; concentration coefficient; total pollution index; biological absorption coefficient; geochemical background; chernozem; locust; geochemical associations; zinc; vanadium; copper; lead; molybdenum; permissible soil contamination.
\end{abstract}

УДК 631.46

Статья поступила в редакцию 26.10.2017

\section{МОДЕЛИРОВАНИЕ РОСТА ГРИБНОГО МИЦЕЛИЯ С ПОМОЩЬЮ КЛЕТОЧНОГО НЕПРЕРЫВНОГО СТОХАСТИЧЕСКОГО АВТОМАТА ЧЕТВЕРТОГО КЛАССА С НЕПРЕРЫВНО ЗАДАННЫМИ УСЛОВИЯМИ РОСТА}

(C) 2017

\author{
Шумилов Анатолий Сергеевич, аспирант, \\ младший научный сотрудник лаборатории математического моделирования экосистем \\ Благодатский Сергей Александрович, доктор биологических наук, \\ ведущий научный сотрудник лаборатории почвенных циклов азота и углерода \\ Институт физико-химических и биологических проблем почвоведения \\ (2. Пущино, Московская область, Российская Федераџия)
}

\begin{abstract}
Аннотация. Целью данной работы являлось моделирование роста и пространственной структуры грибного мицелия с использованием клеточного автомата на основе синтеза различных модельных подходов. Пространственная структура мицелия описывается в структурной подмодели клеточного автомата, которая определяет скорость роста в направлении большего количества ресурсов и количество ветвлений мицелия на единицу площади субстрата. Количество доступного субстрата определяет вероятность однонаправленного апикального роста. Другая, биохимическая, часть модели позволяет описать скорость транспорта ресурсов в клетку, перенос их внутри мицелия, а также их экскрецию и предназначена для описания вертикальной и горизонтальной миграции в почве сразу двух биофильных элементов. Предложенная модель позволяет количественно описать такую особенность роста грибной колонии, как более активное поглощение ресурсов внешними клетками, по сравнению с центральными за счет разделения транспорта ресурсов на активный и пассивный. При этом активный транспорт описывали, используя кинетику Михаэлиса-Ментен. Мы смогли смоделировать запасание избыточных ресурсов и их перераспределение по мицелию после исчерпания запасов во внешней среде, а также имитировать типичные рисунки роста мицелиальных колоний, которые наблюдались в экспериментах, опубликованных в литературе.

Ключевые слова: клеточный автомат; математическое моделирование; модель роста мицелия; рост гриба; микология; экология; кинетика Михаэлиса-Ментен; ветвление гриба; транспорт веществ внутри гриба; мицелярные грибы; биотехнология; пассивное всасывание; активное всасывание; апикальный рост.
\end{abstract}

\section{Введение}

Мицелиальные грибы - важный компонент почвенной микробиоты. На 1 грамм почвы может приходиться до 16 километров грибного мицелия [1]. Сапротрофные грибы участвуют в процессах ферментативного разложения органического вещества почвы ускоряя процессы минерализации азота и фосфора в почве. Кроме этого мицелиальные грибы могут перемещать питательные элементы (азот, углерод, фосфор) по гифам в удаленные участки мицелия, тем самым выравнивая неоднородность среды по ресурсам.
Цель математического моделирования - не только создать систему математических уравнений, которая объясняет и предсказывает поведение реальных систем, но и сделать это как можно более простым способом, так, чтобы можно было легко проверить функциональность структуры модели и верифицировать параметры модели относительно экспериментальных данных используя статистические методы [2].

Существующие простые модели роста грибного мицелия различаются в зависимости от уровня детализации описания происходящих процессов и пространственной структуры гиф [3]. Такие модели 